\title{
Диагностика МДП-структур на основе МЛЭ НgCdTe при высокой плотности медленных поверхностных состояний
}

\author{
А.В.Войцеховский ${ }^{1,2)}$, С.Н.Несмелов ${ }^{1)}$, С.М.Дзядух ${ }^{1)}$, В.С.Варавин ${ }^{3)}$, С.А.Дворецкий ${ }^{1,3)}$, \\ Н.Н.Михайлов ${ }^{3)}$, М.В.Якушев ${ }^{3)}$, Г.Ю.Сидоров ${ }^{3)}$ \\ ${ }^{1}$ Национальный исследовательский Томский государственный университет, \\ Томск, 634050, пр. Ленина, 36 \\ ${ }^{2}$ Сибирский физико-технический институт ТГУ, Томск, 634050, пл. Новособорная, 1 \\ ${ }^{3}$ Институт физики полупроводников им. А.В. Ржанова СО РАН, \\ Новосибирск, 630090, пр. Ак. Лаврентьева, 13 \\ тел:+7 (3822) 41-2772, факс:+7 (3822) 41-2772, эл.nочта: vav43@mail.tsu.ru
}

DOI 10.34077/RCSP2019-157

Проблемой, возникающей при использовании для пассивации поверхности МЛЭ $\mathrm{HgCdTe}$ диэлектрика $\mathrm{Al}_{2} \mathrm{O}_{3}$, сформированного методом плазменного нанесения атомных слоев [1], (а также $\mathrm{SiO}_{2} / \mathrm{Si}_{3} \mathrm{~N}_{4}$ ) является высокая плотность медленных состояний в переходном слое между диэлектрическим покрытием и $\mathrm{HgCdTe}$ [2]. Гистерезисные явления значительно осложняют электрофизическую диагностику МДП-структур. В данной работе исследованы возможности методики измерения первой производной емкости при сложной форме развертки напряжения [3] для характеризации МДП-структур на основе МЛЭ $\mathrm{HgCdTe}$ с приповерхностными варизонными слоями.

Показано, что использование при исследованиях МДП-структур на основе $\mathrm{HgCdTe}$ сложной формы развертки напряжения позволяет определить первую производную емкости по напряжению при различных смещениях с исключением влияния перезарядки медленных поверхностных состояний. При совместном использовании результатов традиционного $\mathrm{C}-\mathrm{V}$ метода и предложенной методики можно построить вольт-фарадные характеристики без искажений, вносимых перезарядкой медленных состояний [4]. Форма полученных зависимостей не зависит от направления изменения напряжения, такие зависимости могут быть использованы для расчета спектров быстрых поверхностных состояний или зависимостей концентрации легирующей примеси от координаты (рисунок). Проведено сравнение экспериментальных результатов с данными численного моделирования.

Расчетная часть исследований проведена при финансовой поддержке РФФИ и Администрации

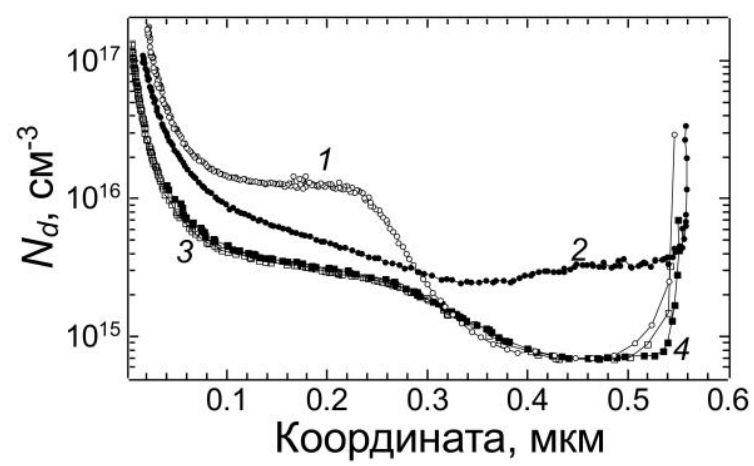

Рисунок. Координатные зависимости концентрации легирующих центров в МДПструктуре на основе МЛЭ $n$ - $\mathrm{Hg}_{0.77} \mathrm{Cd}_{0.23} \mathrm{Te}$, построенные при помощи традиционных измерений $(к \mathrm{k} .1,2)$ и предложенной методики (кр. 3,4$)$ при прямой $(к р .1,3)$ и обратной $(к р .2,4)$ развертке напряжения Томской области в рамках научного проекта р_а № 18-43-700005.

\section{Лumepamypa}

[1] P.Zhang, et al. // J. Electron. Mater. 2016. V. 45, No. 9. P. 4716-4720.

[2] А.В.Войцеховский, С.Н.Несмелов, С.М.Дзядух // Изв. вузов. Физика. 2015. Т. 58, вып. 4. С. 97106.

[3] T.Nakagawa, H.Fujisada // Appl. Phys. Lett. 1977. V. 31, No. 5. P. 348-350.

[4] A.V.Voitsekhovskii, et al. // Vacuum. 2018. V. 158. P. 136-140. 